\title{
Epilepsi og depresjon
}

\author{
Sammendrag \\ Bakgrunn. Depresjoner forekommer \\ hyppigere blant epilepsipasienter enn \\ i den generelle befolkningen. Hos \\ mange har depresjonene større inn- \\ virkning på livskvaliteten enn selve \\ anfallene.
}

Materiale og metode. Grunnlaget for artikkelen er et ikke-systematisk søk i PubMed og egne kliniske erfaringer med pasientgruppen.

Resultater. Fordi depresjonssymptomene hos epilepsipasienter ofte er svingende og noe atypiske sammenliknet med symptomene hos pasienter med depresjon uten epilepsi, kan diagnostikken være vanskelig. Depresjoner kan ha en tidsmessig relasjon til anfallene (iktalt eller periiktalt), men vanligere er depresjoner som opptrer uavhengig av anfallene, dvs. interiktalt. Depresjonene kan ha nevrobiologiske, psykososiale og iatrogene årsaker. Særlig utsatte er de med temporolimbisk epilepsi, fokus i venstre hemisfære og/eller som får GABAerge medikamenter. Antidepressiver kan i enkelte tilfeller senke anfallsterskelen, men dette gjelder ikke, eller i liten grad, SSRI- eller SNRI-preparater. Derfor anbefales disse som førstevalg ved medikamentell behandling av depresjoner i denne pasientgruppen.

Fortolkning. Det er en bidireksjonalitet mellom epilepsi og depresjon, idet den ene tilstanden øker risikoen for den andre og vice versa. I de senere år er det funnet flere felles patofysiologiske mekanismer som vi tror kan forklare dette fenomenet. Depresjoner i epilepsipopulasjonen blir ofte ikke erkjent og følgelig heller ikke behandlet. Vi tror at antidepressiv behandling kan bedre livssituasjonen for mange av disse pasientene.

\section{Oliver Henning}

oliver.henning@oslo-universitetssykehus.no Karl 0. Nakken

Avdeling for kompleks epilepsi

Klinikk for kirurgi og nevrofag

Oslo universitetssykehus

There is an overlap between neurology and psychiatry, and epilepsy has always been central to discussions about this interface.

Michael R. Trimble (1)

Depresjoner anses i dag for å være den hyppigst forekommende komorbide tilstanden hos epilepsipasienter (2). I de senere år er det funnet sterke holdepunkter for at den ene tilstanden gir økt risiko for utvikling av den andre og vice versa. Dessuten synes det å foreligge flere felles patofysiologiske mekanismer ved de to tilstandene.

Hovedbegrunnelsen for å skrive denne artikkelen er at vi etter mange år i dette fagfeltet sitter med et inntrykk av at depresjoner hos pasienter med epilepsi ofte blir oversett og følgelig heller ikke behandlet. Vi tror at relativt enkle tiltak kan bedre denne pasientgruppens livssituasjon.

Psykiatrisk komorbiditet kan i stor grad forringe epilepsipasientenes livskvalitet. Hos dem som ikke er anfallsfrie, påvirkes livskvaliteten mer av de depressive symptomene enn av anfallsfrekvensen (3). I tillegg opplever de med depresjon de epileptiske anfallene som kraftigere og mer plagsomme enn det de med bare epilepsi oppfatter sine anfall. De har også høyere risiko for medikamentrelaterte bivirkninger og større forbruk av helsetjenester (4).

\section{Materiale og metode}

Grunnlaget for artikkelen er et ikke-systematisk søk i PubMed og egne kliniske erfaringer i form av mange års klinisk og forskningsmessig arbeid med epilepsipasienter.

\section{Epidemiologi}

Sikre tall for prevalens og insidens av depresjoner i epilepsipopulasjonen har vi ikke. Resultatene fra forskjellige studier spriker betydelig, og prevalenstallene varierer fra $11 \%$ til $62 \%(5,6)$. Årsakene til de store sprikene ligger trolig i forskjeller mellom de undersøkte populasjonene, manglende konsensus om avgrensning av depresjonsbegrepet $\mathrm{i}$ epilepsipopulasjonen samt bruk av ulike diagnostiske metoder til å avdekke og måle grad av depresjon (3).

Det er likevel ingen tvil om at depresjoner forekommer hyppigere blant epilepsipasienter enn i den generelle befolkning (5) og hyppigere enn blant pasienter med andre kroniske sykdommer, som for eksempel astma $(7,8)$.

Depresjoner forekommer ved alle epilepsiformer, men er særlig prevalent ved temporolimbisk epilepsi (3), muligens på grunn av felles patofysiologiske mekanismer.

\section{Atypisk semiologi}

Depresjoner i epilepsipopulasjonen skiller seg ofte fra symptombildet ved primære alvorlige eller lette depresjoner ved sine mer pleomorfe og svingende symptomer. Tilstanden har blant annet vært kalt epilepsirelatert dystymi (dysthymic-like disorder of epilepsy) (2). Hovedsymptomene er gjengitt i ramme 1 og er i overensstemmelse med forslaget til klassifikasjon av nevropsykiatriske lidelser hos epilepsipasienter fra International League Against Epilepsy (9).

Tilstanden fyller som oftest ikke de diagnostiske kriteriene som er satt for depresjoner i diagnoseverktøyene Diagnostic and statistical manual of mental disorders (DSM-IV-TR) (10) eller den internasjonale statistiske klassifikasjon av sykdommer og beslektede helseproblemer (ICD-10) (11) og blir av den grunn ofte oversett (12).

\section{Depresjonene kan ha relasjon til anfallene}

Depresjonsperioder blant epilepsipasienter kan opptre med en tidsmessig relasjon til anfallene eller være uavhengig av disse. Man skiller gjerne mellom periiktale, iktale og interiktale depresjoner (fig 1).

Periiktale depresjoner er redusert stem-

\section{Hovedbudskap}

- Ved epilepsi er depresjon den hyppigst forekommende komorbide tilstanden

- Depresjon øker ikke bare risikoen for epilepsiutvikling, men også for at epilepsien blir terapiresistent

- Flere av de samme patofysiologiske mekanismene er operante ved begge tilstandene

- SSRI- og SNRI-preparater er førstevalget ved psykofarmakologisk behandling av interiktale depresjoner 
ningsleie før eller etter epileptiske anfall. Mange med epilepsi har prodromalsymptomer 1-3 døgn forut for anfall i form av dysfori og irritabilitet (13). Mange pårørende hevder de dermed kan forutsi anfallene.

Blant pasienter med behandlingsrefraktær fokal epilepsi opplever $40-50 \%$ postiktale depressive symptomer, inkludert suicidtanker hos $13 \%(9,14)$. Symptomene, i form av tristhet og følelsen av håpløshet, skyld og skam, kan komme etter et symptomfritt intervall på opptil en uke etter anfallet og varer gjerne 1-2 døgn.

Iktale depresjoner ses hos rundt $15 \%$ (15) av dem med aura og opptrer som oftest hos pasienter med temporolimbisk epilepsi der den iktale epileptiske aktiviteten involverer amygdala. De fleste med slik aura opplever en intens og ubegripelig angst, mens noen føler en bunnløs tristhet «som kommer ut av det blå» (16).

Interiktale depresjoner er den vanligste formen for depresjon i epilepsipopulasjonen (17). Den kan ha høyst forskjellig varighet og alvorlighetsgrad. De depressive periodene opptrer uten tidsmessig relasjon til anfallene, og pasientene kan ved siden av nedstemthet og en følelse av verdiløshet ha nevrovegetative, kognitive og somatiske symptomer med dårlig appetitt, vekttap, søvnforstyrrelser, tretthet og redusert konsentrasjonsevne.

\section{Mange mulige årsaker}

Trolig er det ved depresjoner i epilepsipopulasjonen en kompleks blanding av nevrobiologiske og psykososiale årsaksfaktorer.

Epileptogene lesjoner med strukturelle og funksjonelle endringer i limbiske strukturer, også kalt «the emotional brain», gir økt risiko for psykiske problemer, inkludert depresjoner. I en klinisk studie med pasienter med temporallappsepilepsi (der limbiske strukturer som oftest er affisert) er det ved siden av kognitive vansker funnet at pasientene hadde redusert emosjonell og sosial kompetanse samt høyere skår på angst- og depresjonsskalaer enn matchede kontrollpersoner (18).

Antiepileptika kan ha både positive og negative psykotrope effekter. Spesielt karbamazepin, valproat og lamotrigin har stemningsstabiliserende egenskaper. Depresjoner kan oppstå som følge av seponering av et slikt medikament. Andre antiepileptika, slike som levetiracetam (19) og medikamenter som påvirker gammaaminosmørsyremedikamenter (GABAerge medikamenter) som fenobarbital, primidon, vigabatrin, tiagabin, felbamat og topiramat, kan ha negative psykotrope effekter, inkludert depresjoner (2).

Opptil 30\% av pasientene som gjennomgår temporallappsreseksjoner pga. farmakoresistent epilepsi har depresjoner det første året etter operasjonen, enten som forsterkning av tidligere depresjonstendens eller som de novo-depresjoner (20). Dette gjelder også dem som etter operasjonen er blitt anfallsfrie, mange av disse får store problemer med omstilling til den nye rollen som frisk.
Depresjoner er vist å være en negativ prediktor for å bli anfallsfri, ikke bare etter epilepsikirurgi, men også ved behandling med antiepileptika (21).

For mange er det å få epileptiske anfall et betydelig psykisk traume. Epilepsi er dessverre fortsatt en mytebefengt sykdom, og mange opplever diskriminering og stigmatisering. Tilbakevendende anfall som kommer uten forvarsel, kan dessuten skape angst og utrygghet. Kombinert med manglende førerkort kan resultatet fort bli en passiv og isolert tilværelse med uføretrygd. ikke uvanlig. Disse barna ender ofte opp med lav selvfølelse, dårlig sosial kompetanse og uselvstendighet (22).

\section{Flere risikofaktorer}

Noen epilepsipasienter ser ut til å være mer utsatt enn andre for å utvikle affektive tilleggsproblemer. Noen disponerende faktorer er gjengitt i ramme 2 .

Det hersker bred enighet om at pasienter med temporolimbisk epilepsi er særlig sårbare, men betydningen av lateralitet av fokus er omdiskutert. Enkelte PET- og SPECT-studier tyder på en overhyppighet av depresjoner blant dem med epileptisk fokus i venstre hemisfære (23).

\section{$\emptyset$ kt risiko for suicid}

I epilepsipopulasjonen er suicidrisikoen fem ganger så høy som i den generelle befolkningen (24). Spesielt høy er risikoen de første seks måneder etter at diagnosen er stilt og hos pasienter med psykiatrisk komorbiditet. For pasienter med temporale komplekse partielle anfall er risikoen økt 25 ganger (25). I en multisenterstudie med 139 pasienter gikk $12,2 \%$ med suicidtanker, og livstidsprevalensen for suicidforsøk var 20,8\% (25).

Food and Drug Administration (FDA) i USA sendte i 2008 et «FDA alert»-brev til
Overbeskyttelse av barn med epilepsi er

\section{Ramme 1}

Hovedsymptomer ved epilepsirelatert dystymi (dysthymic-like disorder of epilepsy) (2)

- Nedstemthet, gledesløshet

- Følelse av håpløshet

- Gråtetokter

- Lav selvfølelse

- Tretthet

- Lavt energiforråd

- Angst

- Irritabilitet, lav frustrasjonsterskel

- Spiseforstyrrelser

- Søvnforstyrrelser

amerikanske leger om økt suicidrisiko ved bruk av antiepileptika. Advarselen var basert på en gjennomgang av rapporterte bivirkninger fra 199 kliniske studier av 11 antiepileptika. I ettertid har dette brevet vært gjenstand for mye kritikk. Mange mente det vitenskapelige belegget for advarselen var svært tynn og at den forhøyede suicidraten $\mathrm{i}$ denne pasientgruppen heller skyldtes epilepsien enn behandlingen (26).

\section{Epilepsi gir økt risiko for depresjon og vice versa}

At epilepsi kan ledsages av depresjoner, har vært kjent lenge, men at depresjoner gir økt risiko for epilepsiutvikling, er relativt ny viten. Både hos barn og voksne er det funnet 3-4 ganger økt risiko for å utvikle epileptiske anfall og epilepsi hvis vedkommende på forhånd hadde hatt alvorlige depresjoner $(27,28)$. Cramer og medarbeidere fant en
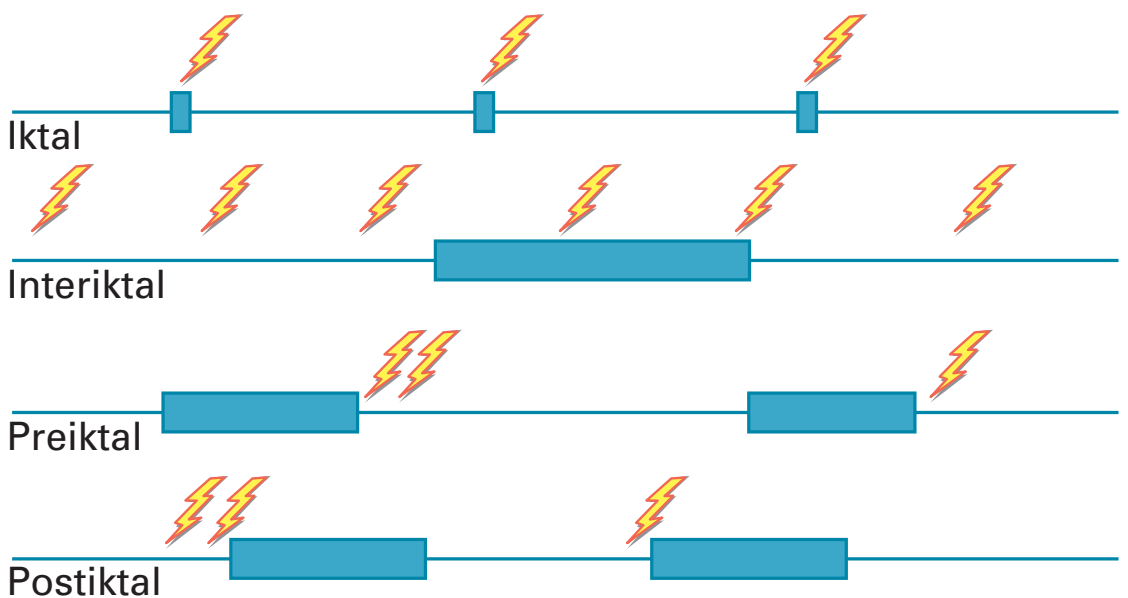

Depresjon

Anfall

Figur 1 Tidsmessig relasjon mellom epileptiske anfall og psykiatriske symptomer 

Ramme 2
Risikofaktorer for å utvikle
depresjon ved epilepsi (2)
- Depresjoner i familien
- Temporolimbisk epilepsi
- Epileptisk fokus i venstre hemisfære
- Polyfarmasi, inkludert GABAerge medikamenter
- Dårlig tilpasning til epilepsien
- Høyt stressnivå
- Kjønn: kvinne
- Seksuell dysfunksjon
- Dårlig økonomi
- Dårlig sosialt nettverk

nær relasjon mellom depresjon og epilepsiens alvorlighetsgrad (4). Disse data sier intet om kausalitet, bare at de to tilstandene påvirker hverandre gjensidig.

\section{Flere patofysiologiske fellestrekk}

Det er både dyreeksperimentelle og kliniske holdepunkter for flere felles nevrobiologiske forstyrrelser ved de to tilstandene. Dette kan kanskje forklare bidireksjonaliteten. Både epilepsi og depresjon kan oppfattes som uttrykk for et dysfunksjonelt cerebralt cellenettverk. To patogene mekanismer er trolig operante ved begge tilstandene (29):

- Endrede konsentrasjoner av hjernens nevrotransmittere, inkludert serotonin, noradrenalin, dopamin, GABA og glutamat

- Strukturelle og funksjonelle endringer i frontotemporale områder, spesielt innen de limbiske strukturer

Det er i dag flere indikasjoner på at det ved så vel temporallappsepilepsi som depresjoner er en endret interaksjon mellom serotonerge og noradrenerge nevroner på den ene side og glutamaterge systemer på den annen (29). Dette resulterer i abnorme cellulære nettverk preget av hypereksitabilitet. Man antar at slik nevronal hypereksitabilitet, særlig i limbiske strukturer, ikke bare kan gi anfall, men også emosjonelle forstyrrelser (29). Redusert serotonerg og noradrenerg aktivitet, som er vist å foreligge hos mange med alvorlige depresjoner, kombinert med høye stressbetingede glukokortikoidnivåer, påvirker danningen av nevrotrope faktorer, noe man tror er forklaringen på hippocampusatrofien man kan se ved begge tilstandene. I MR- og PET-studier er det ved både epilepsi og depresjoner funnet morfologiske og metabolske endringer ikke bare temporalt, men også frontalt (30).

Studier av dyremodeller av epilepsi har vist at økt serotonerg aktivitet kan ha antikonvulsive effekter (31), og hos epilepsipasienter kan antidepressiver av typen selektive serotoninreopptakshemmere (SSRI) ha et visst antikonvulsivt potensial (32), samtidig som den positive psykotrope effekten av lamotrigin, karbamazepin og valproat kan være formidlet via økte serotoninnivåer. Man har også spekulert på om den antiepileptiske og den antidepressive effekten av vagusnervestimulering er formidlet gjennom øt noradrenerg og serotonerg aktivitet (33).

Også astrocytter, som er intimt bundet til glutamatmetabolismen, ser ut til spille en viktigere rolle enn tidligere antatt både ved depresjoner og epilepsi. Ved begge tilstander er det funnet en endret glia-nevron-interaksjon. Mens det ved temporallappsepilepsi er funnet nevrontap med innvekst av gliaceller i hippocampus, noe som antas å bidra til hypereksitabiliteten (34), er det ved alvorlige depresjoner funnet nedsatt antall astrocytter i frontallappen, med lave nivåer av glutamat, glutamin og GABA (35).

\section{Diagnostikk}

Å diagnostisere depresjon bos epilepsipasienter kan være vanskelig. Både pasient og lege kan oppfatte symptomene som en naturlig reaksjon på et liv med plutselige og uforutsigbare anfall, som ledd i selve epilepsien eller som bivirkninger av antiepileptika. Pasientene opplyser sjelden om slike symptomer spontant, og hvis legen ikke spør direkte om depresjon, blir resultatet underrapportering og underbehandling.
Tabell 1 Gilliam og medarbeideres Neurological Disorder Depression Inventory for Epilepsy (NDDI-E) (39). En samlet skår > 15 indikerer en sannsynlig depresjon, og pasienten bør da utredes ytterligere. Den norske oversettelsen er utført av forfatterene, og er ikke validert i en norsk populasjon

\begin{tabular}{lcccc} 
& Altid/ofte & Av og til & Sjelden & Aldri \\
\hline Livet er en kamp & 4 & 3 & 2 & 1 \\
\hline Ingenting av det jeg gjør er riktig & 4 & 3 & 2 & 1 \\
\hline Jeg føler skyld & 4 & 3 & 2 & 1 \\
Jeg kunne like godt vært død & 4 & 3 & 2 & 1 \\
Jeg er frustrert & 4 & 3 & 2 & 1 \\
Jeg har problemer med å finne gleder & 4 & 3 & 2 & 1
\end{tabular}

I tillegg til et målrettet klinisk intervju kan symptomer på depresjon fanges opp ved bruk av enkle spørreskjemaer som Becks Depression Inventory (BDI) (36), Hospital Anxiety and Depression Scale (HADS) (37), Montgomery and Aasberg Depression Rating Scale (MADRS) (38) eller Neurological Disorders Depression Inventory for Epilepsy (NDDI-E) (39). Etter vår erfaring er NDDI-E best egnet til rask screening $i$ en travel klinisk hverdag. Den er utviklet spesielt for diagnostisering av depressive symptomer hos epilepsipasienter og inneholder seks påstander som er vist å ha god korrelasjon med forekomst av depresjon, men ikke med medikamentbivirkninger (tab 1). Den er enkel og rask å fylle ut, og en svarskår på 15 eller høyere indikerer en sannsynlig depresjon. For ytterligere diagnostikk anbefaler vi BDI-skjemaet.

Selv om de nevnte spørreskjemaene kan gi rask indikasjon på om det foreligger en depresjon, og ev. graden av denne, kan de likevel ikke erstatte et godt klinisk intervju.

\section{Påvirker antidepressiver anfallsterskelen?}

Ved behandlingstrengende interiktale depresjoner bør man benytte et stemningsstabiliserende antiepileptikum. Ved behov for ytterligere antidepressiv behandling er SSRImidler og serotonin- og noradrenalinreopptakshemmere (SNRI) førstevalget. Disse er effektive, de tolereres relativt godt og de påvirker vanligvis ikke anfallsterskelen. Dessverre finnes det ingen placebokontrollerte studier av behandling av interiktale depresjoner hos epilepsipasienter. Registreringsstudier av SSRI- og SNRI-preparater har imidlertid vist at de som fikk slike medikamenter, hadde signifikant farre epileptiske anfall enn placebogruppen (40). Mange klinikeres vegring for å gi antidepressiver av frykt for å forsterke anfallstendensen hos deprimerte epilepsipasienter synes derfor ugrunnet, i hvert fall om man benytter SSRIog SNRI-preparater i moderate doser og med langsom doseopptrapping.

\section{Interaksjoner mellom antiepileptika og antidepressiver}

SSRI- og SNRI-preparater metaboliseres i leveren via P-450-systemet, og metabolismen akselereres av enzyminduserende antiepileptika, slike som fenobarbital, fenytoin og karbamazepin.

Noen antidepressiver, for eksempel fluoksetin, paroksetin og fluvoksamin er enzyminhibitorer. Kombineres et av disse stoffene med et enzyminduserende antiepileptikum, kan man få subterapeutiske konsentrasjoner av det antidepressive midlet og toksiske konsentrasjoner av det antiepileptiske (41). Jevnlig monitorering av serumkonsentrasjonen av begge midlene er derfor tilrådelig.

Citalopram, escitalopram og venlafaksin er de antidepressiver som påvirker P-450isoenzymer minst (41). 


\section{Andre terapiformer}

Ved Avdeling for kompleks epilepsi - SSE har vi mange års erfaring med miljøterapi i grupper. Mange depressive epilepsipasienter profitterer på slik gruppeterapi og på uformelle samtaler med medpasienter i samme situasjon. Andre kan ha nytte av både psykofarmakologisk behandling og individualisert psykoterapi hos psykolog eller psykiater, etter vår erfaring kanskje særlig kognitiv terapi.

Hos pasienter med alvorlige depresjoner som ikke responderer på antidepressiver, kan elektrosjokkbehandling (ECT) være verdt å forsøke. ECT er ikke kontraindisert ved epilepsi, og enkelte studier har faktisk vist at slik behandling kan heve anfallsterskelen (42).

\section{Konklusjon}

Depresjoner forekommer hyppig blant epilepsipasienter. En slik komorbiditet kan være et større problem enn selve anfallene og er ofte forbundet med redusert livskvalitet og betydelig forbruk av helsetjenester. Dessuten øker depresjoner risikoen for at epilepsien blir terapiresistent. Atypiske symptomer og manglende kunnskap hos legene fører ofte til underdiagnostisering. I tillegg tror vi frykten for at antidepressiver skal senker anfallsterskele, kan bidra til underbehandling.

Pasienter med epilepsi og depresjon kan behandles med SSRI- og SNRI-preparater uten risiko for anfallsforverring. Bidireksjonaliteten mellom epilepsi og depresjon kan bedre forstås ettersom det nå er holdepunkter for at det finnes flere felles patofysiologiske mekanismer.

\section{Oliver Henning (f. 1965)}

er dr.med. og spesialist i nevrologi og psykiatri. Han har vært avdelingsoverlege ved Nevrologisk avdeling i Ålesund og fra 2003 overlege ved Avdeling for kompleks epilepsi (tidligere SSE), Oslo universitetssykehus. Spesiell interesse er epileptologien i grensefeltet mellom nevrologi og psykiatri.

Ingen oppgitte interessekonflikter.

\section{Karl O. Nakken (f. 1945)}

er spesialist i nevrologi og dr.med. og tok doktorgraden med en avhandling om fysisk aktivitet blant personer med epilepsi. Han er seksjonsoverlege og medisinsk fagansvarlig ved Avdeling for kompleks epilepsi, Oslo universitetssykehus.

\section{Ingen oppgitte interessekonflikter.}

\section{Litteratur}

1. Trimble MR. Overview: Psychiatric issues. I: Engel J jr., Pedley TA, red. Epilepsy. A comprehensive textbook. 2. utg. Philadelphia: Lippincott, Williams \& Wilkins, 2008: 2075-6

2. Barry JJ, Lembke A, Gisbert PA et al. Affective dis orders in epilepsy. I: Ettinger AB, Kanner AM, red. Psychiatric issues in epilepsy. A practical guide to diagnosis and treatment. Philadelphia: Lippincott Williams \& Wilkins, 2007: 203-47.

3. Gilliam F. Optimizing health outcomes in active epilepsy. Neurology 2002; 58 (8 suppl 5): S9-20.
4. Cramer JA, Blum D, Reed M et al; Epilepsy Impac Project Group. The influence of comorbid depression on seizure severity. Epilepsia 2003; 44 $1578-84$.

5. Tellez-Zenteno JF, Patten SB, Jetté $\mathrm{N}$ et al. Psychiatric comorbidity in epilepsy: a populationbased analysis. Epilepsia 2007; 48: 2336-44.

6. Altshuler L. Depression and epilepsy. I: Devinsky O, Theodore WH, red. Epilepsy and behavior. New York: Wiley-Liss, 1991: 47-65.

7. Ettinger A, Reed M, Cramer J; Epilepsy Impact Project Group. Depression and comorbidity in community-based patients with epilepsy or asthma. Neurology 2004: 63: 1008-14.

8. Mendez MF, Doss RC, Taylor JL et al. Depression in epilepsy. Relationship to seizures and anticonvulsant therapy. J Nerv Ment Dis 1993; 181: 444-7.

9. Krishnamoorthy ES, Trimble MR, Blumer D. The classification of neuropsychiatric disorders in epilepsy: a proposal by the ILAE Commission on Psychobiology of Epilepsy. Epilepsy Behav 2007; 10 349-53.

10. Diagnostic and Statistical Manual of Mental Disorders. 4. utg. (DSM-IV-TR). Text Revision. Washington D.C.: American Psychiatric Association, 2000.

11. Den internasjonale statistiske klassifikasjon av sykdommer og beslektede helseproblemer. 10 revisjon (ICD-10). Norsk utgave 2005. Oslo: Sosialog helsedirektoratet, 2005

12. Mendez MF, Cummings JL, Benson DF. Depression in epilepsy. Significance and phenomenology. Arch Neurol 1986; 43: 766-70.

13. Blanchet P. Frommer GP. Mood change preceding epileptic seizures. J Nerv Ment Dis 1986; 174 : 471-6.

14. Kanner AM, Soto A, Gross-Kanner H. Prevalence and clinical characteristics of postictal psychiatric symptoms in partial epilepsy. Neurology 2004; 62 $708-13$

15. Weil AA. Ictal emotions occurring in temporal lobe dysfunction. Arch Neurol 1959; 1: 87-97.

16. Daly D. Ictal affect. Am J Psychiatry 1958; 115 97-108

17. Kanner AM, Weisbrot DM. Psychiatric evaluation of the adult and pediatric patient with epilepsy: a practical approach for the the «nonpsychiatrist». I: Ettinger AB, Kanner AM, red. Psychiatric issues in epilepsy. A practical guide to diagnosis and treatment. 2. utg. Philadelphia: Lippincott Wil liams \& Wilkins, 2007: 119-32.

18. Walpole P, Isaac CL, Reynders HJ. A comparison of emotional and cognitive intelligence in people with and without temporal lobe epilepsy. Epilepsia 2008; 49: 1470-4

19. Mula M, Sander JW. Negative effects of antiepileptic drugs on mood in patients with epilepsy. Drug Saf 2007; 30: 555-67.

20. Kanner AM, Tilwalli S, Byrne R. Psychiatric and neurologic predictors of postsurgical psychiatric complications following temporal lobectomy. Neurology 2004; 64: A-358

21. Hitiris N, Mohanraj R, Norrie J et al. Predictors of pharmacoresistant epilepsy. Epilepsy Res 2007 75: $192-6$.

22. Chaplin JE, Yepez R, Shorvon S et al. A quantitative approach to measuring the social effects of epilepsy. Neuroepidemiology 1990; 9: $151-8$

23. Victoroff JI, Benson F, Grafton ST et al. Depression in complex partial seizures. Electroencephalography and cerebral metabolic correlates. Arch Neurol 1994; 51: 155-63.

24. Jones JE, Hermann BP, Barry JJ et al. Rates and risk factors for suicide, suicidal ideation, and suicide attempts in chronic epilepsy. Epilepsy Behav 2003; 4 (suppl 3): S31-8.

25. Barraclough B. Suicide and epilepsy. I: Reynolds EH, Trimble MR, red. Epilepsy and psychiatry. Edinburgh: Churchill Livingstone, 1981: 72-6.

26. Hesdorffer DC, Kanner AM. The FDA alert on suicidality and antiepileptic drugs: Fire or false alarm? Epilepsia 2009; 50: 978-86

27. Forsgren L, Nyström L. An incident case-referent study of epileptic seizures in adults. Epilepsy Res 1990: 6: 66-81

28. Hesdorffer DC, Hauser WA, Annegers JF et al. Major depression is a risk factor for seizures in older adults. Ann Neurol 2000; 47: 246 -9.

29. Kondziella D, Alvestad S, Vaaler A et al. Which clinical and experimental data link temporal lobe epilepsy with depression? J Neurochem 2007; 103: $2136-52$
30. Kanner AM. Is major depression a neurologic disorder with psychiatric symptoms? Epilepsy Behav 2004; 5: 636-44.

31. López-Meraz ML, González-Trujano ME, NeriBazán L et al. 5-HT1A receptor agonists modify epileptic seizures in three experimental models in rats. Neuropharmacology 2005; 49: 367-75.

32. Jobe PC, Browning RA. The serotonergic and noradrenergic effects of antidepressant drugs are anticonvulsant, not proconvulsant. Epilepsy Behav 2005; 7: 602-19.

33. Nahas Z, Marangell LB, Husain MM et al. Twoyear outcome of vagus nerve stimulation (VNS) for treatment of major depressive episodes. J Clin Psychiatry 2005; 66: 1097-104

34. Rogawski MA. Astrocytes get in the act in epilepsy Nat Med 2005; 11: 919-20.

35. Hasler G, van der Veen JW. Tumonis T et al. Reduced prefrontal glutamate/glutamine and gamma-aminobutyric acid levels in major depres sion determined using proton magnetic resonance spectroscopy. Arch Gen Psychiatry 2007; 64: 193-200.

36. Beck AT, Ward CH, Mendelson M et al. An inventory for measuring depression. Arch Gen Psychiatry 1961; 4: $561-71$

37. Zigmond AS, Snaith RP. The hospital anxiety and depression scale. Acta Psychiatr Scand 1983; 67: 361-70.

38. Montgomery SA, Åsberg M. A new depression scale designed to be sensitive to change. $\mathrm{Br}$ J Psychiatry 1979; 134: 382-9.

39. Gilliam FG, Barry JJ, Hermann BP et al. Rapid detection of major depression in epilepsy: a multicentre study. Lancet Neurol 2006; 5: 399-405.

40. Alper K, Schwartz KA, Kolts RL et al. Seizure incidence in psychopharmacological clinical trials: an analysis of Food and Drug Administration (FDA) summary basis of approval reports. Biol Psychiatry 2007; 62: 345-54

41. Kanner AM, Gidal BE. Pharmacodynamic and pharmacokinetic interactions of psychotropic drugs with antiepileptic drugs. Int Rev Neurobiol 2008; 83: 397-416.

42. Coffey CE, Lucke J, Weiner RD et al. Seizure threshold in electroconvulsive therapy (ECT) II. The anticonvulsant effect of ECT. Biol Psychiatry 1995: 37 : 777-88.

Mottatt 29.6. 2010, første revisjon innsendt 23.12. 2010, godkjent 3.3. 2011. Medisinsk redaktør Are Brean. 